DOI: $10.15193 /$ zntj/2018/114/220

\author{
DOROTA LITWINEK, HALINA GAMBUŚ, KRZYSZTOF BUKSA, \\ MAŁGORZATA MAKAREWICZ, GABRIELA ZIĘĆ, FLORIAN GAMBUŚ, \\ MAGDALENA KOWALCZYK, JAKUB BORECZEK
}

\title{
JAKOŚĆ I PROCES STARZENIA SIĘ CHLEBÓW Z RAZOWYCH MĄK PSZENNYCH: Z PSZENICY ZWYCZAJNEJ I ORKISZ ORAZ Z ŻYTA
}

\author{
Streszczenie
}

Celem pracy była ocena jakości chlebów z razowej mąki pszennej z pszenicy zwyczajnej i orkiszowej oraz z żyta, uzyskanych na zakwasie spontanicznym z mąki razowej z danego zboża oraz określenie procesu starzenia się tego pieczywa w trakcie przechowywania. W piekarni „Vini” sporządzono z wymienionych trzech mąk razowych zakwasy spontaniczne i dodano je w odpowiedniej proporcji do sporządzenia ciasta. Z 600-gramowych kęsów ciasta wypieczono chleby i po ochłodzeniu oznaczono ich masę, zmierzono objętość, wyliczono stratę wypiekową całkowitą oraz wykonano ocenę organoleptyczną. We wszystkich chlebach oznaczono zawartość: wody, białka ogółem, błonnika pokarmowego (frakcji rozpuszczalnej i nierozpuszczalnej), popiołu (wybranych makro- i mikroelementów), tłuszczu surowego, wybranych mikotoksyn, fosforanów mio-inozytolu, substancji kształtujących smak i zapach oraz akryloamidu. Wykonano również pomiary profilu tekstury miękiszu w dniu wypieku oraz podczas 7-dobowego przechowywania. Oznaczono liczbę tlenowych bakterii amylolitycznych (OLBA), liczbę tlenowych przetrwalnikujących bakterii amylolitycznych (OLBAP), liczbę drożdży i pleśni (OLG) w $1 \mathrm{~g}$ pieczywa oraz trwałość termostatową pieczywa po 1., 2., 5. i 7. dobie przechowywania.

Największą objętością wyróżniały się chleby z mąki z pszenicy zwyczajnej graham i one też uzyskały najlepszą akceptację konsumentów w ocenie organoleptycznej, zwłaszcza za smak i zapach. Chleby żytnie i z mąki z pszenicy orkisz cechowały się podobną objętością bochenków, przy czym chleby żytnie w większym stopniu niż orkiszowe były akceptowane przez konsumentów. W chlebach z mąki pszennej, zarówno graham, jak i orkiszowej oznaczono zbliżony stosunek zawartości kwasu mlekowego do octowego - średnio $78: 22$, natomiast w chlebie żytnim udział kwasu mlekowego był mniejszy, octowego większy niż w pieczywie pszennym, a stosunek zawartości kwasu mlekowego do octowego wynosił śred-

Dr inż. D. Litwinek, prof. dr hab. inż. H. Gambuś, dr hab. inż. K. Buksa, dr G. Zięć, Katedra Technologii Węlowodanów, dr M. Makarewicz, Katedra Technologii Fermentacji i Mikrobiologii Technicznej, Wydz. Technologii Żywności, Uniwersytet Rolniczy w Krakowie, ul. Balicka 122, 30-149 Kraków, prof. dr hab. inż. F. Gambuś, Katedra Chemii Rolnej i Środowiskowej, Wydz. Rolniczo-Ekonomiczny, Uniwersytet Rolniczy w Krakowie, al. Mickiewicza 21, 31-120 Kraków, dr M. Kowalczyk, mgr inż. J. Boreczek, Zakład Biochemii Drobnoustrojów, Instytut Biochemii i Biofizyki PAN, ul. Pawińskiego 5A, 02-106 Warszawa.Kontakt:dorota.litwinek@urk.edu.pl 
nio 68 : 32. W chlebie razowym żytnim oznaczono największą zawartość glukozy. W chlebach razowych pszennych, zarówno orkiszowych, jak i graham, w odróżnieniu od chlebów żytnich, oznaczono zarówno niższe fosforany mio-inozytolu $\left(\mathrm{IP}_{3} \mathrm{i} \mathrm{IP}_{2}\right)$, jak i wyższe fosforany tego związku - $\mathrm{IP}_{5}$ i $\mathrm{IP}_{4}$. W razowych chlebach orkiszowych nie oznaczono nawet śladowych zawartości akryloamidu, a w pozostałych chlebach ilości tego związku były śladowe. Badane chleby wykazały dużą trwałość mikrobiologiczną. W dniu wypieku największą wilgotnością miękiszu odznaczały się chleby żytnie (ok. 50 \%), natomiast średnia wilgotność miękiszu chlebów pszennych (orkiszowych i graham) wynosiła ok. 47,5\%. Po 7 dobach przechowywania wilgotność miękiszu wszystkich chlebów zmniejszyła się w bardzo małym stopniu - o 0,5 1 p.p., mimo to zaobserwowano postępujący wzrost jego twardości podczas przechowywania, najmniejszy w chlebach żytnich.

Słowa kluczowe: chleb razowy na zakwasie: z mąki żytniej, z mąki z pszenicy zwyczajnej i orkisz, zakwas spontaniczny, jakość chleba, starzenie się chleba

\section{Wprowadzenie}

Prowadzona kampania medialna na rzecz prawidłowego odżywiania powoduje, że jedyną grupą asortymentową wśród wyrobów piekarskich wykazującą wzrost produkcji są wyroby z mąk z pełnego przemiału [11]. Spożycie chlebów z mąki razowej polecane jest przez specjalistów ds. żywienia człowieka jako bardzo bogatych we włókno pokarmowe i wiele składników bioaktywnych, które nadają im charakteru żywności o działaniu prozdrowotnym. Pieczywo takie jest ponadto zalecane w dietach odchudzających, ponieważ charakteryzuje się niskim indeksem glikemicznym (ok. 50) w odróżnieniu od pieczywa z mąki jasnej $(70 \div 95)$. Pieczywo to spełnia zalecenia WHO w programie zwalczania otyłości. Coraz większa świadomość konsumentów wymusza na producentach dbałość o odpowiednią podaż na rynku pieczywa o działaniu funkcjonalnym, wyprodukowanego zarówno z tradycyjnych surowców chlebowych, tj. z razowej mąki pszennej i żytniej, jak również z surowców niekonwencjonalnych, a nawet reliktowych, tj. z mąki orkiszowej (Triticum spelta) [15, 26, 28].

Wyprodukowanie smacznego i akceptowanego chleba żytniego wymaga ukwaszenia mąki, natomiast pieczywo pszenne (w tym orkiszowe) wypiekane jest głównie $\mathrm{z}$ udziałem drożdży w procesie fermentacji alkoholowej. Obecnie do produkcji zakwasów piekarskich stosuje się kultury starterowe, stąd zalecane jest stosowanie ukwaszania wszystkich rodzajów mąki ze względu na korzystne procesy zachodzące podczas jej fermentacji, przede wszystkim wytwarzanie kwasów organicznych wpływających na smak i aromat pieczywa, produkcję witamin z grupy B, inaktywację organizmów patogennych, rozkład fitynianów, a tym samym zwiększenie przyswajalności składników mineralnych, rozkład mikotoksyn i wydłużenie procesu świeżości pieczywa $[2$, $15]$.

Jak wykazali inni autorzy we wcześniejszych badaniach, chleby uzyskane z mąki całoziarnowej z pszenicy orkisz nie odznaczały się większą wartością odżywczą [26] 
czy też większą zawartością związków bioaktywnych [30] niż chleby z mąki z pszenicy zwyczajnej [28]. Nie nadają się one również do stosowania w diecie bezglutenowej [14]. Ze względu jednak na dużą zawartość białka w ziarnie pszenicy orkisz i możliwość uprawy ekologicznej tego zboża, wydaje się uzasadnione stosowanie całoziarnowej mąki orkiszowej do produkcji chleba [16].

$\mathrm{Z}$ uwagi na żywieniowo istotną rolę zakwasu piekarskiego, chleby z mąki z pszenicy orkisz należałoby prowadzić na zakwasie. W dostępnej literaturze znajduje się tylko jedna publikacja, w której autorzy użyli kultury starterowej do ukwaszenia całoziarnowej mąki orkiszowej [8]. Inni autorzy $[4,26]$ do sporządzenia ciasta z całoziarnowej mąki orkiszowej zastosowali wyłącznie drożdże. El-Sayed i Rabalski [8] po ukwaszeniu mąki orkiszowej uzyskali chleb o mniejszej objętości i niżej oceniony pod względem cech organoleptycznych w porównaniu z chlebem otrzymanym z całoziarnowej mąki z pszenicy HRS.

Celem pracy była ocena jakości chlebów z razowej mąki pszennej z pszenicy zwyczajnej i orkiszowej oraz z mąki żytniej uzyskanych na zakwasie spontanicznym sporządzonym z wyżej wymienionych mąk oraz analiza procesu starzenia się tego pieczywa w trakcie przechowywania.

\section{Material i metody badań}

Materiałem do badań były: 2 mąki graham oraz 2 mąki razowe z pszenicy orkisz i 2 razowe mąki żytnie, używane do wypieku chlebów razowych w piekarni „Vini” w Rogoźniku Śląskim.

Zakwasy spontaniczne sporządzano według opisu zawartego w publikacji Litwinek i wsp. [18]. Ciasto o temp. $37^{\circ} \mathrm{C}$ sporządzano z poszczególnych mąk, zgodnie $\mathrm{z}$ recepturami podanymi w tab. $1-3$.

Zarówno zakwasy z mąki pszennej i mąki żytniej, jak i ciasto na wszystkie ww. chleby razowe sporządzano w piekarni „Vini”. Ciasto dzielono na kęsy o masie $600 \mathrm{~g}$, kształtowano i fermentowano w foremkach przez $4 \mathrm{~h}$ w warunkach piekarni. Wypiek prowadzono w temp. $210^{\circ} \mathrm{C}$ przez $1 \mathrm{~h}$.

Chleby wypiekano $\mathrm{z}$ udziałem zakwasów fermentowanych $\mathrm{w}$ procesie spontanicznym. Ze względu na brak powtarzalności jakości chlebów z udziałem różnych zakwasów sporządzonych $\mathrm{z}$ tego samego rodzaju mąki, każdy wypiek traktowano indywidualnie. Analizowano 6 rodzajów chleba z zakwasem spontanicznym: chleb żytni z pierwszej partii (VSZ1), chleb żytni z drugiej partii (VSZ2), chleb pszenny z pierwszej partii (VSP1), chleb pszenny z drugiej partii (VSP2), chleb orkiszowy z pierwszej partii (VSO1), chleb orkiszowy z drugiej partii (VSO2).

Wykonywano pomiar masy zimnych bochenków i obliczano średnią masę pieczywa. Na podstawie uzyskanych wyników i receptury obliczano wydajność pieczywa oraz całkowitą stratę wypiekową [13]. Mierzono również objętość bochenków w apa- 
racie Volscan Profiler (Stable Micro System, Wielka Brytania) i obliczano średnią objętość pieczywa. Analizy wykonano w 6 powtórzeniach z każdego rodzaju chleba.

Tabela 1. Receptura ciasta $\mathrm{z}$ razowej mąki żytniej

Table 1. Recipe for dough from wholemeal rye flour

\begin{tabular}{|c|c|c|c|}
\hline $\begin{array}{l}\text { Sposób dodawania } \\
\text { Way of adding }\end{array}$ & Mąka żytnia / Rye flour [kg] & Woda / Water $[\mathrm{kg}]$ & Sól / Salt [kg] \\
\hline $\begin{array}{l}\text { Dodawana do dzieży } \\
\text { Added to vessel }\end{array}$ & 35,75 & 22,0 & $\begin{array}{l}0,83 \text { ( } 2 \% \text { masy mąki } \\
\text { / of flour weight })\end{array}$ \\
\hline \multirow{2}{*}{$\begin{array}{c}\text { Dodana z zakwasem } \\
\text { Added with } \\
\text { sourdough }\end{array}$} & $\begin{array}{l}4,84 \text { (12\% masy mąki / of } \\
\text { flour weight) }\end{array}$ & 7,26 & \multirow[t]{2}{*}{ 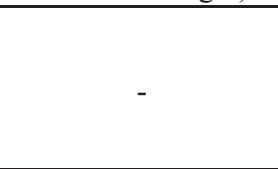 } \\
\hline & \multicolumn{2}{|c|}{$\begin{array}{c}\text { Łącznie } 12,10 \mathrm{~kg} \text { zakwasu } \\
\text { In total } 12.10 \mathrm{~kg} \text { of sourdough }\end{array}$} & \\
\hline $\begin{array}{l}\text { Całkowita ilość } \\
\text { Total amount }\end{array}$ & 40,59 & 29,26 & 0,83 \\
\hline
\end{tabular}

Objaśnienia / Explanatory notes:

Wydajność zakwasu z mąki żytniej wynosiła 250 \%, a wydajność ciasta - 172 \% / Yield of rye sourdough was $250 \%$ and yield of dough: $172 \%$.

Tabela 2. Receptura ciasta z razowej mąki pszennej orkiszowej

Table 2. Recipe for dough from wholemeal spelt wheat flour

\begin{tabular}{|c|c|c|c|}
\hline $\begin{array}{l}\text { Sposób dodawania } \\
\text { Way of adding }\end{array}$ & $\begin{array}{c}\text { Mąka z pszenicy orkisz } \\
\text { Flour from spelt wheat }[\mathrm{kg}]\end{array}$ & Woda / Water [kg] & Sól / Salt [kg] \\
\hline $\begin{array}{l}\text { Dodawana do dzieży } \\
\text { Added to vessel }\end{array}$ & 34,38 & 24,09 & $\begin{array}{c}0,66(1,7 \% \text { masy mąki } \\
\text { / of flour weight })\end{array}$ \\
\hline \multirow{2}{*}{$\begin{array}{l}\text { Dodana z zakwasem } \\
\text { Added with } \\
\text { sourdough }\end{array}$} & $\begin{array}{c}3,45 \text { (9\% masy mąki / flour } \\
\text { mass })\end{array}$ & 5,19 & \multirow[t]{2}{*}{ 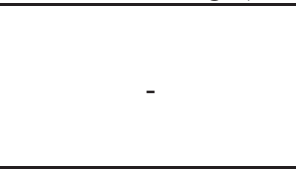 } \\
\hline & \multicolumn{2}{|c|}{$\begin{array}{c}\text { Łącznie } 8,64 \mathrm{~kg} \text { zakwasu } \\
\text { In total } 8.64 \mathrm{~kg} \text { of sourdough }\end{array}$} & \\
\hline $\begin{array}{l}\text { Całkowita ilość } \\
\text { Total amount }\end{array}$ & 37,83 & 29,28 & 0,66 \\
\hline
\end{tabular}

Objaśnienia / Explanatory notes:

Wydajność zakwasu z mąki orkiszowej wynosiła $250 \%$, a wydajność ciasta - 177 \% / Yield of sourdough from spelt wheat flour was $250 \%$ and yield of dough: $177 \%$.

Otrzymane chleby poddawano ocenie organoleptycznej metodą punktową według PN-A-74108:1996 [22] przez minimum 15-osobowy panel o sprawdzonej wrażliwości sensorycznej. Badano cechy jakościowe pieczywa, tj. wygląd zewnętrzny, barwę i grubość skórki, elastyczność i porowatość miękiszu, smak i zapach. Każdy rodzaj pieczywa kwalifikowano do odpowiedniej klasy jakości. 
Tabela 3. Receptura ciasta $\mathrm{z}$ razowej mąki z pszenicy zwyczajnej

Table 3. Recipe for dough from wholemeal common wheat flour

\begin{tabular}{|c|c|c|c||}
\hline $\begin{array}{c}\text { Sposób dodawania } \\
\text { Way of adding }\end{array}$ & $\begin{array}{c}\text { Mąka z pszenicy zwyczajnej } \\
\text { Flour from common wheat }[\mathrm{kg}]\end{array}$ & $\begin{array}{c}\text { Woda / Water } \\
{[\mathrm{kg}]}\end{array}$ & Sól / Salt $[\mathrm{kg}]$ \\
\hline $\begin{array}{c}\text { Dodawana do dzieży } \\
\text { Added to vessel }\end{array}$ & 38,75 & 18,20 & $\begin{array}{c}0,73(1,7 \text { \% masy mąki } \\
\text { / of flour weight })\end{array}$ \\
\hline $\begin{array}{c}\text { Dodana z zakwasem } \\
\text { Added with } \\
\text { sourdough }\end{array}$ & $\begin{array}{c}4,48(10 \% \text { masy mąki / of flour } \\
\text { weight })\end{array}$ & 6,72 & - \\
\cline { 2 - 3 } & $\begin{array}{c}\text { Lącznie } 11,2 \mathrm{~kg} \text { zakwasu } \\
\text { In total } 11.2 \mathrm{~kg} \text { of sourdough }\end{array}$ & \multirow{2}{*}{0,73} \\
\hline $\begin{array}{c}\text { Całkowita ilość } \\
\text { Total amount }\end{array}$ & 43,12 & 24,92 & \\
\hline \hline
\end{tabular}

Objaśnienia / Explanatory notes:

Wydajność zakwasu z mąki pszennej wynosiła $240 \%$, a wydajność ciasta - $158 \%$ / Yield of sourdough from wheat flour was $240 \%$ and yield of dough: $158 \%$.

W chlebach utrwalonych przez powietrzne wysuszenie w minimum 2 powtórzeniach oznaczano zawartość: popiołu (według AOAC 930.05 [1]), wybranych składników mineralnych (według AOAC 985.01 [1]), białka ogółem (według AOAC 950.36 [1]), błonnika pokarmowego (według AOAC 991.43 [1]), tłuszczu surowego (według AOAC 930.05 [1]) oraz zawartość akryloamidu metodą HPLC/UV według Paleologosa i Kontaminasa [20] z modyfikacją własną polegającą na odbiałczaniu otrzymanych ekstraktów roztworami Carreza i odwirowaniu przez 25 min z prędkością $12000 \mathrm{rpm}$. W świeżym miękiszu oznaczano zawartość: wybranych mikotoksyn zgodnie z instrukcją obsługi aparatu Rapid-Kinetik-Assay ${ }^{\circledR}$ (Aokin AG, Niemcy), fosforanów mioinozytolu według Chena i Li [6] oraz substancji kształtujących aromat pieczywa - metodą HPLC/UV, którą opisali Levebvre i wsp. [17]. Spośród związków aromatycznych oznaczano zawartość kwasów organicznych (mlekowego, octowego, propionowego, jabłkowego, winowego i cytrynowego), cukrów (maltozy i glukozy) oraz alkoholi (glicerolu i etanolu). Ponadto określano kwasowość potencjalną miękiszu chlebów metodą miareczkową według PN-A-74108:1996 [22].

Wykonywano również analizę wilgotności miękiszu chlebów metodą suszarkową (według AOAC 925.10 [1]) oraz profilu tekstury miękiszu analizatorem tekstury TA.XT Plus (Stable Micro Systems, Wielka Brytania). Pomiar tekstury wykonywano testem TPA w środku kromki o grubości $3 \mathrm{~cm}$ przy użyciu sondy aluminiowej P-20, z szybkością przesuwu sondy $5 \mathrm{~mm} \cdot \mathrm{s}^{-1}$. Mierzono odkształcenie w warstwie o grubości $50 \%$ całkowitej wysokości próbki. Przy użyciu oprogramowania Exponent v. 4.0.13.0. i standardowego programu makro dla testu TPA (Stable Micro Systems, Wielka Brytania) mierzono twardość, spójność, żujność oraz odbojność miękiszu. 
Otrzymane chleby przechowywano przez 7 dób. W celu określenia zmian zachodzących podczas starzenia się pieczywa wykonywano analizę wilgotności i profilu tekstury miękiszu po 1., 2., 5. i 7. dobie przechowywania metodami podanymi wyżej.

Wszystkie analizy chlebów wykonywano minimum w dwóch powtórzeniach. Uzyskane wyniki poddano jednoczynnikowej analizie wariancji (ANOVA) w programie Statistica 10. Istotność różnic między wartościami średnimi weryfikowano testem Duncana przy $\mathrm{p} \leq 0,05$.

Trwałość mikrobiologiczną pieczywa wyznaczano metodą termostatową PN-A-74102:1999 [25]. Wykonywano również posiewy mikrobiologiczne mające na celu określenie w 1 g pieczywa: liczby tlenowych bakterii amylolitycznych (OLBA), liczby tlenowych przetrwalnikujących bakterii amylolitycznych (OLBAP) - zgodnie z PN-A-74134-4:1998 [23], liczby drożdży i pleśni (OLG) - zgodnie z PN-A-74134-6:1998 [24]. Wszystkie analizy mikrobiologiczne wykonywano w trzech powtórzeniach w 1., 5. i 7. dobie przechowywania pieczywa.

\section{Wyniki i dyskusja}

Uzyskane zakwasy zostały użyte do sporządzenia ok. $70 \mathrm{~kg}$ ciasta. Stosowano zbliżone, ale nie identyczne ilości poszczególnych surowców, tj. mąki, zakwasu, soli i wody, tak, aby uzyskać porównywalną konsystencję ciasta z różnych mąk. Ukwaszona mąka razowa wprowadzona do ciasta w formie zakwasu stanowiła $9 \%$ całości mąki orkiszowej, 11 \% całości mąki pszennej graham i $12 \%$ mąki żytniej (tab. 1 - 3).

Największa ilość zakwasu w cieście żytnim wynikała z konieczności największego ukwaszenia mąki żytniej ze względu na potrzebę zahamowania działania $\alpha$-amylazy i umożliwienia utworzenia struktury ciasta. Ponadto w środowisku kwaśnym ciasta pszennego i żytniego uaktywnia się enzym fitaza (co zwiększa dostępność pierwiastków) oraz enzymy proteolityczne, co prowadzi do utworzenia związków aromatycznych oraz związków przeciwbakteryjnych. Tworzą się ponadto egzopolisacharydy biorące udział w kształtowaniu struktury ciasta i opóźnianiu starzenia się chleba $[2,7]$. Z ww. powodów w cieście żytnim zastosowano największy udział soli (3\%), która również przyczynia się do zmniejszenia aktywności amylolitycznej.

Strata wypiekowa całkowita wszystkich ocenianych chlebów zawierała się w przedziale $12 \div 15,5 \%$, przy czym nie była ona zależna od rodzaju badanego pieczywa (tab. 4). Najmniejszą stratą wypiekową odznaczał się chleb VS01 z mąki orkiszowej MO1, w której oznaczono o 3,5 \% więcej glutenu mokrego niż w mące orkiszowej MO2 [18]. Chleb z mąki VSO2 charakteryzował się za to istotnie większą objętością w porównaniu z chlebem VSO1.

Największą objętością wyróżniały się chleby z mąki graham z pszenicy zwyczajnej (tab. 4) i one też zyskały największą akceptację konsumentów w ocenie organoleptycznej (tab. 4). Należy podkreślić, że w ocenie organoleptycznej chleby razowe 
z mąki z pszenicy zwyczajnej zostały wyróżnione największą liczbą punktów ze względu na smak i zapach. Mimo że chleby żytnie i orkiszowe były zbliżone pod względem objętości, to jednak większą akceptacją konsumencką - ze względu na smak i zapach - wyróżniały się chleby żytnie (tab. 4).

Preferencje konsumentów mogły być związane ze stosunkiem kwasu mlekowego do octowego w chlebach, gdyż wskaźnik ten w największym stopniu wpływa na smak i zapach pieczywa na zakwasie. W chlebach pszennych graham oznaczono trzykrotnie większą ilość kwasu mlekowego niż octowego (tab. 5), podobnie jak w chlebach orkiszowych, które jednak zyskały mniejszą akceptację konsumentów (tab. 4). Chleby te odznaczały się też zbliżoną kwasowością miękiszu (tab. 5). Interesujące wydaje się to, że mimo największej kwasowości miękiszu spowodowanej prawdopodobnie większą obecnością kwasu octowego, w odniesieniu do pozostałych chlebów, razowy chleb żytni bardziej smakował oceniającym niż orkiszowy. Być może wpłynęła na tę ocenę największa zawartość glukozy oznaczona w tym chlebie (tab. 6), wyraźnie większa w porównaniu z innymi chlebami, co mogło nadać miękiszowi chleba żytniego ciekawy, słodko-kwaśny smak i wyrazisty zapach związany z większą zawartością kwasu octowego. Najmniejszą zawartość maltozy i glukozy oznaczono w chlebie orkiszowym VS01, w którym jednocześnie odnotowano ok. 10-krotnie większą zawartość etanolu w porównaniu z pozostałymi chlebami (tab. 6).

Jak wynika $\mathrm{z}$ danych zawartych w tab. 4., chleby wypieczone $\mathrm{z}$ udziałem zakwasów fermentowanych spontanicznie należy traktować indywidualnie ze względu na brak powtarzalności jakości chlebów z różnych zakwasów z tego samego rodzaju mąki.

Największą zawartość białka oznaczono w chlebach z mąki orkiszowej, pośrednią - w chlebach z mąki z pszenicy zwyczajnej, zaś najmniejszą (w porównaniu z chlebami orkiszowymi nawet o połowę mniejszą) - w chlebach z razowej mąki żytniej (tab. 7). Jest to przypuszczalnie wynikiem różnic zawartości białka w mąkach, co przedstawiono we wcześniejszej publikacji [18], z których ten chleb wypieczono.

Mimo wykazanej statystycznej istotności różnic pod względem zawartości tłuszczu, wyniki analizy tego składnika we wszystkich rodzajach chlebów należy uznać za porównywalne, bowiem oznaczona zawartość thuszczu powyżej $2 \%$, a nawet $3 \%$, najprawdopodobniej pochodzi z tłuszczu dodanego, stosowanego do smarowania form.

Analizowane chleby charakteryzowały bardzo niewielkie, ale istotne różnice pod względem zawartości substancji mineralnych w postaci popiołu (tab. 7), choć najmniejszą jego ilość oznaczono w chlebach z mąki pszennej graham, co uwidoczniło się w najmniejszej zawartości potasu $(\mathrm{K})$ - tab. 8. oraz miedzi $(\mathrm{Cu})-$ tab. 9. w tych chlebach. Największa zawartość popiołu w chlebie z mąki orkiszowej VSO1 (tab. 7) skutkowała natomiast największą zawartością fosforu (P) - tab. 8., żelaza (Fe) i cynku (Zn) - tab. 9. w tym chlebie. 


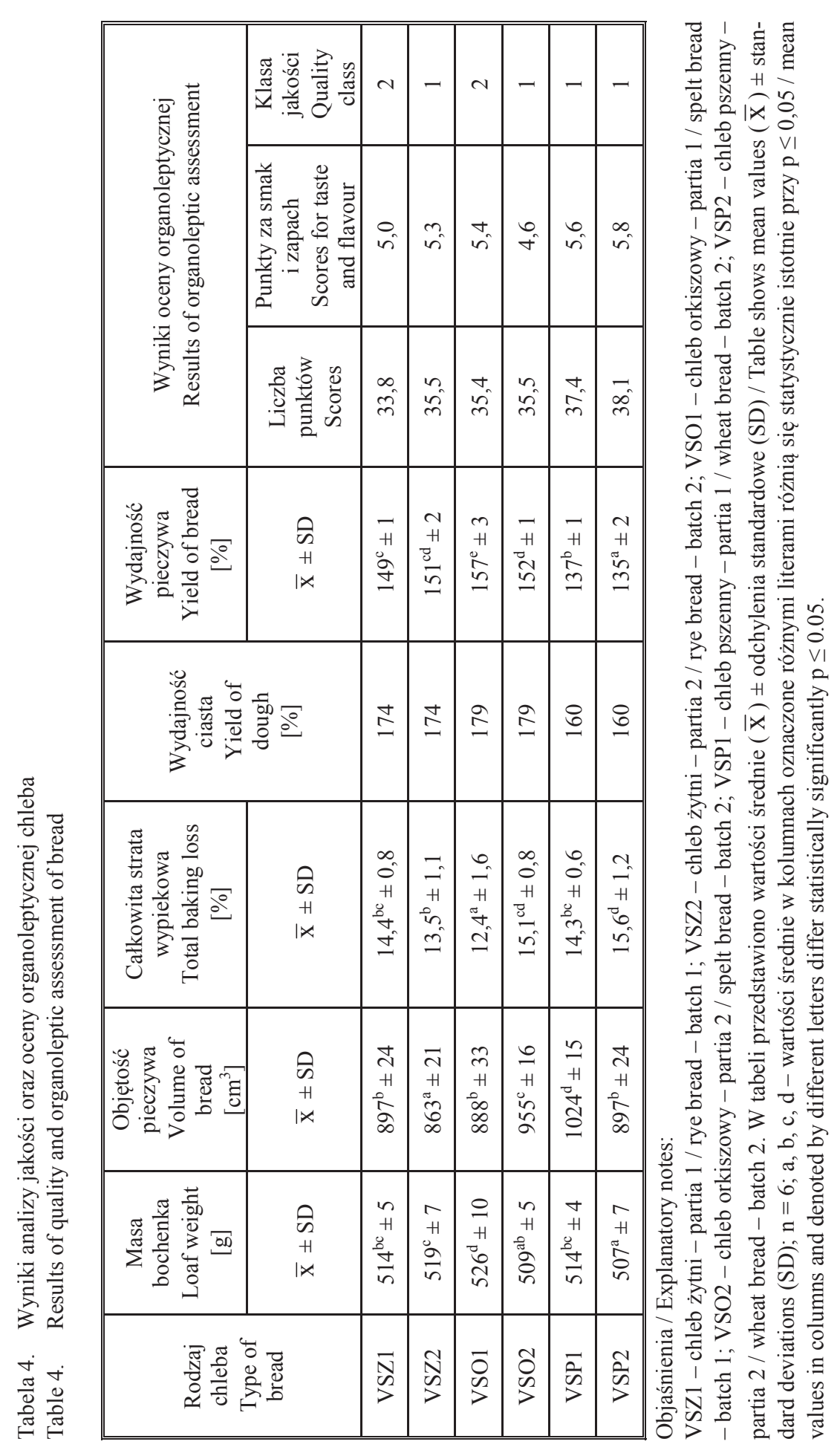




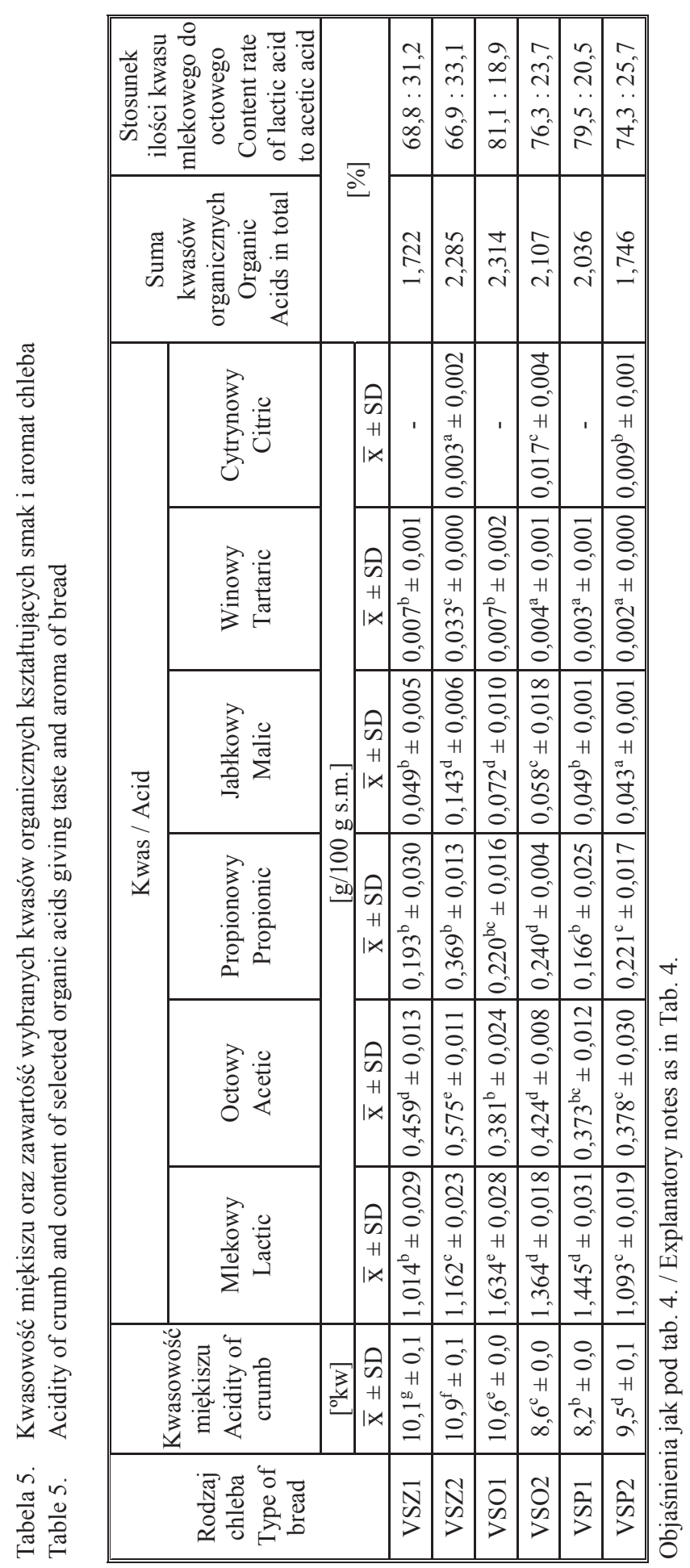


Tabela 6. Zawartość wybranych cukrów i alkoholi kształtujących smak i aromat chleba

Table 6. Content of selected sugars and alcohols giving taste and aroma of bread

\begin{tabular}{||c|c|c|c|c||}
\hline \multirow{2}{*}{$\begin{array}{c}\text { Rodzaj } \\
\text { chleba }\end{array}$} & \multicolumn{3}{|c||}{ Zawartość $[\mathrm{g} / 100 \mathrm{~g} \mathrm{s.m.]} /$ Content [g/100 g d.m.] } \\
\cline { 2 - 5 } $\begin{array}{c}\text { Type of } \\
\text { bread }\end{array}$ & \multicolumn{2}{|c|}{ Cukry / Sugars } & \multicolumn{2}{c||}{ Alkohole / Alcohols } \\
\cline { 2 - 5 } & Maltoza / Maltose & Glukoza / Glucose & Glicerol / Glycerin & Etanol / Ethanol \\
\cline { 2 - 5 } & $\overline{\mathrm{x}} \pm$ SD & $\overline{\mathrm{x}} \pm \mathrm{SD}$ & $\overline{\mathrm{x}} \pm \mathrm{SD}$ & $\overline{\mathrm{x}} \pm$ SD \\
\hline VSZ1 & $0,4188^{\mathrm{c}} \pm 0,0097$ & $0,5519^{\mathrm{e}} \pm 0,0040$ & $0,2251^{\mathrm{a}} \pm 0,0264$ & $0,0779^{\mathrm{d}} \pm 0,0010$ \\
\hline VSZ2 & $0,8924^{\mathrm{d}} \pm 0,0006$ & $0,8378^{\mathrm{e}} \pm 0,0207$ & $0,2592^{\mathrm{ab}} \pm 0,0185$ & $0,0504^{\mathrm{b}} \pm 0,0029$ \\
\hline VSO1 & $0,0369^{\mathrm{a}} \pm 0,0003$ & $0,0909^{\mathrm{a}} \pm 0,0156$ & $0,2831^{\mathrm{b}} \pm 0,017$ & $0,5233^{\mathrm{b}} \pm 0,0018$ \\
\hline VSO2 & $0,3628^{\mathrm{c}} \pm 0,0181$ & $0,3803^{\mathrm{d}} \pm 0,0218$ & $0,2726^{\mathrm{c}} \pm 0,0232$ & $0,0530^{\mathrm{c}} \pm 0,0019$ \\
\hline VSP1 & $0,4173^{\mathrm{c}} \pm 0,0137$ & $0,2794^{\mathrm{c}} \pm 0,0070$ & $0,2147^{\mathrm{a}} \pm 0,0039$ & $0,0410^{\mathrm{a}} \pm 0,0035$ \\
\hline VSP2 & $0,2318^{\mathrm{b}} \pm 0,0010$ & $0,1435^{\mathrm{b}} \pm 0,0006$ & $0,2639^{\mathrm{b}} \pm 0,0017$ & $0,0506^{\mathrm{b}} \pm 0,0012$ \\
\hline
\end{tabular}

Objaśnienia jak pod tab. 4. / Explanatory notes as in Tab. 4.

Tabela 7. Podstawowy skład chemiczny badanych chlebów

Table 7. Basic chemical composition of bread studied

\begin{tabular}{|c|c|c|c|c|}
\hline $\begin{array}{l}\text { Rodzaj } \\
\text { chleba } \\
\text { Type of } \\
\text { bread }\end{array}$ & $\begin{array}{c}\text { Sucha masa } \\
{[\mathrm{g} / 100 \mathrm{~g} \text { próbki }]} \\
\text { Dry mass } \\
{[\mathrm{g} / 100 \mathrm{~g} \text { sample }]}\end{array}$ & $\begin{array}{c}\text { Białko ogółem } \\
\text { [g/100 g s.m.] } \\
\text { Total protein } \\
\text { [g/100 g d.m.] }\end{array}$ & $\begin{array}{c}\text { Tłuszcz surowy } \\
\text { [g/100 g s.m.] } \\
\text { Raw fat } \\
\text { [g/100 g d.m.] }\end{array}$ & $\begin{array}{l}\text { Związki mineralne w } \\
\text { postaci popiołu } \\
\text { [g/100 g s.m.] } \\
\text { Mineral compounds } \\
\text { in form of total ash } \\
\text { [g/100 g d.m. }]\end{array}$ \\
\hline & $\overline{\mathrm{x}} \pm \mathrm{SD}$ & $\overline{\mathrm{x}} \pm \mathrm{SD}$ & $\overline{\mathrm{x}} \pm \mathrm{SD}$ & $\overline{\mathrm{x}} \pm \mathrm{SD}$ \\
\hline VSZ1 & $92,65^{\mathrm{d}} \pm 0,02$ & $7,05^{\mathrm{a}} \pm 0,02$ & $2,28^{\mathrm{a}} \pm 0,03$ & $3,65^{\mathrm{d}} \pm 0,02$ \\
\hline VSZ2 & $90,44^{\mathrm{c}} \pm 0,08$ & $7,53^{\mathrm{b}} \pm 0,05$ & $3,25^{\mathrm{e}} \pm 0,11$ & $3,54^{\mathrm{c}} \pm 0,01$ \\
\hline VSO1 & $93,05^{\mathrm{e}} \pm 0,03$ & $14,58^{\mathrm{f}} \pm 0,00$ & $2,96^{\mathrm{d}} \pm 0,02$ & $3,72^{\mathrm{e}} \pm 0,02$ \\
\hline $\mathrm{VSO} 2$ & $90,35^{\mathrm{c}} \pm 0,06$ & $13,39^{\mathrm{e}} \pm 0,23$ & $3,04^{\mathrm{d}} \pm 0,01$ & $3,30^{\mathrm{b}} \pm 0,01$ \\
\hline VSP1 & $89,98^{\mathrm{a}} \pm 0,05$ & $12,18^{\mathrm{c}} \pm 0,04$ & $2,71^{\mathrm{c}} \pm 0,07$ & $3,07^{\mathrm{a}} \pm 0,02$ \\
\hline VSP2 & $90,10^{b} \pm 0,03$ & $12,70^{\mathrm{d}} \pm 0,02$ & $2,51^{\mathrm{b}} \pm 0,12$ & $3,09^{\mathrm{a}} \pm 0,02$ \\
\hline
\end{tabular}

Objaśnienia jak pod tab. 4. / Explanatory notes as in Tab. 4.

Z danych literaturowych wiadomo, że zawartość składników mineralnych jest zwykle związana z zawartością błonnika pokarmowego w chlebach. Składniki te w największych ilościach znajdują się bowiem w zewnętrznych warstwach ziarniaków [3]. Zależności takie nie zostały jednak potwierdzone w analizowanych chlebach, gdyż największą zawartość błonnika (15 \%) oznaczono w chlebie żytnim VSZ2 (tab. 10), o przeciętnej zawartości popiołu (tab. 7). Natomiast chleb VSO1 z mąki orkiszowej o największej zawartości popiołu odznaczał się zawartością błonnika (13,3\%) zbliżoną do zawartości tego składnika w chlebie z mąki z pszenicy zwyczajnej VSP2 - 12,9 \% (tab. 10), w której oznaczono najmniejszą zawartość popiołu (tab. 7). 
Tabela 8. Zawartość makroelementów w badanych chlebach [mg/kg s.m.]

Table 8. Content of macroelements in bread studied [mg $/ \mathrm{kg} \mathrm{d.m.]}$

\begin{tabular}{|c|c|c|c|c|c||}
\hline Rodzaj chleba & $\mathrm{Mg}$ & $\mathrm{K}$ & $\mathrm{P}$ & $\mathrm{Ca}$ & $\mathrm{Na}$ \\
\cline { 2 - 6 } Type of bread & $\overline{\mathrm{x}} \pm \mathrm{SD}$ & $\overline{\mathrm{x}} \pm \mathrm{SD}$ & $\overline{\mathrm{x}} \pm \mathrm{SD}$ & $\overline{\mathrm{x}} \pm \mathrm{SD}$ & $\overline{\mathrm{x}} \pm \mathrm{SD}$ \\
\hline VSZ1 & $1085^{\mathrm{a}} \pm 10$ & $4554^{\mathrm{bc}} \pm 591$ & $3269^{\mathrm{a}} \pm 182$ & $194^{\mathrm{a}} \pm 1$ & $8153^{\mathrm{b}} \pm 484$ \\
\hline VSZ2 & $1118^{\mathrm{a}} \pm 2$ & $4292^{\mathrm{abc}} \pm 324$ & $3472^{\mathrm{ab}} \pm 108$ & $271^{\mathrm{c}} \pm 2$ & $7906^{\mathrm{b}} \pm 72$ \\
\hline VSO1 & $1765^{\mathrm{d}} \pm 98$ & $4726^{\mathrm{c}} \pm 99$ & $5206^{\mathrm{d}} \pm 156$ & $304^{\mathrm{d}} \pm 19$ & $6378^{\mathrm{a}} \pm 149$ \\
\hline VSO2 & $1324^{\mathrm{c}} \pm 26$ & $4322^{\mathrm{bc}} \pm 144$ & $4107^{\mathrm{c}} \pm 7$ & $293^{\mathrm{d}} \pm 6$ & $6598^{\mathrm{a}} \pm 47$ \\
\hline VSP1 & $1238^{\mathrm{b}} \pm 19$ & $3889^{\mathrm{ab}} \pm 0$ & $3591^{\mathrm{b}} \pm 10$ & $245^{\mathrm{b}} \pm 5$ & $6509^{\mathrm{a}} \pm 19$ \\
\hline VSP2 & $1237^{\mathrm{b}} \pm 8$ & $3579^{\mathrm{a}} \pm 51$ & $3596^{\mathrm{b}} \pm 45$ & $305^{\mathrm{d}} \pm 7$ & $6369^{\mathrm{a}} \pm 180$ \\
\hline
\end{tabular}

Objaśnienia jak pod tab. 4. / Explanatory notes as in Tab. 4.

Tabela 9. Zawartość makroelementów w badanych chlebach [mg/kg s.m.]

Table 9. Content of microelements in bread studied [ $\mathrm{mg} / \mathrm{kg} \mathrm{d.m}$.]

\begin{tabular}{|c|c|c|c|c||}
\hline \hline \multirow{2}{*}{$\begin{array}{c}\text { Rodzaj chleba } \\
\text { Type of bread }\end{array}$} & $\mathrm{Cu}$ & $\mathrm{Fe}$ & $\mathrm{Mn}$ & $\mathrm{Zn}$ \\
\cline { 2 - 5 } & $\overline{\mathrm{x}} \pm \mathrm{SD}$ & $\overline{\mathrm{x}} \pm \mathrm{SD}$ & $\overline{\mathrm{x}} \pm \mathrm{SD}$ & $\overline{\mathrm{x}} \pm \mathrm{SD}$ \\
\hline VSZ1 & $4,02^{\mathrm{c}} \pm 0,09$ & $64,9^{\mathrm{ab}} \pm 4,1$ & $44,2^{\mathrm{e}} \pm 0,4$ & $28,7^{\mathrm{a}} \pm 0,1$ \\
\hline VSZ2 & $3,49^{\mathrm{b}} \pm 0,05$ & $73,2^{\mathrm{b}} \pm 3,6$ & $39,2^{\mathrm{d}} \pm 0,2$ & $30,9^{\mathrm{b}} \pm 0,3$ \\
\hline VSO1 & $4,35^{\mathrm{d}} \pm 0,09$ & $104,6^{\mathrm{d}} \pm 0,1$ & $28,4^{\mathrm{a}} \pm 0,7$ & $33,5^{\mathrm{c}} \pm 0,9$ \\
\hline VSO2 & $4,82^{\mathrm{e}} \pm 0,10$ & $62,3^{\mathrm{a}} \pm 3,7$ & $34,9^{\mathrm{c}} \pm 0,2$ & $32,7^{\mathrm{c}} \pm 0,3$ \\
\hline VSP1 & $2,96^{\mathrm{a}} \pm 0,03$ & $82,6^{\mathrm{c}} \pm 3,6$ & $27,2^{\mathrm{a}} \pm 0,3$ & $32,5^{\mathrm{c}} \pm 0,2$ \\
\hline VSP2 & $2,95^{\mathrm{a}} \pm 0,11$ & $56,1^{\mathrm{a}} \pm 5,0$ & $30,0^{\mathrm{b}} \pm 0,9$ & $29,0^{\mathrm{a}} \pm 1,3$ \\
\hline
\end{tabular}

Objaśnienia jak pod tab. 4. / Explanatory notes as in Tab. 4.

Tabela 10. Zawartość błonnika pokarmowego w badanych chlebach [g/100 g s.m.]

Table 10. Content of dietary fibre in investigated breads $[\mathrm{g} / 100 \mathrm{~g} \mathrm{~d} . \mathrm{m}$.]

\begin{tabular}{||c|c|c|c||}
\hline \hline \multirow{2}{*}{$\begin{array}{c}\text { Rodzaj chleba } \\
\text { Type of bread }\end{array}$} & $\begin{array}{c}\text { Frakcja nierozpuszczalna } \\
\text { Insoluble fraction }\end{array}$ & $\begin{array}{c}\text { Frakcja rozpuszczalna } \\
\text { Soluble fraction }\end{array}$ & $\begin{array}{c}\text { Błonnik ogółem } \\
\text { Total fibre }\end{array}$ \\
\cline { 2 - 4 } & $\overline{\mathrm{x}} \pm \mathrm{SD}$ & $\overline{\mathrm{x}} \pm \mathrm{SD}$ & $\overline{\mathrm{X}} \pm \mathrm{SD}$ \\
\hline VSZ1 & $9,51^{\mathrm{a}} \pm 0,04$ & $2,63^{\mathrm{c}} \pm 0,05$ & $12,15^{\mathrm{b}} \pm 0,08$ \\
\hline VSZ2 & $11,33^{\mathrm{d}} \pm 0,02$ & $3,72^{\mathrm{e}} \pm 0,03$ & $15,04^{\mathrm{e}} \pm 0,05$ \\
\hline VSO1 & $10,34^{\mathrm{c}} \pm 0,04$ & $2,99^{\mathrm{d}} \pm 0,08$ & $13,34^{\mathrm{d}} \pm 0,05$ \\
\hline VSO2 & $9,37^{\mathrm{a}} \pm 0,17$ & $2,24^{\mathrm{b}} \pm 0,05$ & $11,61^{\mathrm{a}} \pm 0,13$ \\
\hline VSP1 & $10,25^{\mathrm{bc}} \pm 0,01$ & $1,34^{\mathrm{a}} \pm 0,10$ & $11,59^{\mathrm{a}} \pm 0,11$ \\
\hline VSP2 & $10,06^{\mathrm{b}} \pm 0,13$ & $2,84^{\mathrm{d}} \pm 0,03$ & $12,90^{\mathrm{c}} \pm 0,10$ \\
\hline
\end{tabular}

Objaśnienia jak pod tab. 4. / Explanatory notes as in Tab. 4.

Na skutek działania bakterii kwasu mlekowego i drożdży w czasie fermentacji kwasowej rozkładowi ulegają fosforany mio-inozytolu, dzięki czemu zostają uwolnione składniki mineralne związane w mące przez te związki i dopiero w takiej formie mogą być przyswojone przez organizm ludzki. Fermentacja spontaniczna zakwasów 
sporządzonych z razowych mąk pszennych (z pszenicy zwyczajnej i orkiszowej) oraz z mąki żytniej spowodowała we wszystkich chlebach znaczące zmniejszenie zawartości fosforanów mio-inozytolu w stosunku do surowców, czyli mąk razowych użytych do wypieku [18].

Najmniejszą zawartość sześciofosforanów inozytolu (0,02 i 0,04 \% s.m.) - tab.11, oznaczono w chlebach żytnich, podczas gdy w razowej mące żytniej występują one w ilości 1,65 \% s.m. [18]. Zmniejszenie zawartości tych związków należy szacować na ok. 80-krotne.

Tabela 11. Zawartość fosforanów mio-inozytolu w badanych chlebach

Table 11. Content of myo-inositol phosphates in bread studied

\begin{tabular}{|c|c|c|c|c|c|c|}
\hline \multirow{3}{*}{$\begin{array}{l}\text { Rodzaj } \\
\text { chleba } \\
\text { Type of } \\
\text { bread }\end{array}$} & \multirow{3}{*}{$\begin{array}{l}\text { Zawartość } \\
\text { suchej masy } \\
\text { w próbce } \\
\text { Content of } \\
\text { dry matter in } \\
\text { sample [\%] }\end{array}$} & \multicolumn{2}{|c|}{$\begin{array}{l}\text { Zawartość fosforanów } \\
\text { mio-inozytolu [\% s.m.] } \\
\text { Content of myo-inositol } \\
\text { phosphates [\% d.m.] }\end{array}$} & \multicolumn{2}{|c|}{$\begin{array}{c}\text { Zawartość fosforanów } \\
\text { mio-inozytolu }[\mu \mathrm{mol} / \mathrm{g} \mathrm{s} \text { s.m] } \\
\text { Content of myo-inositol phos- } \\
\text { phates }[\mu \mathrm{mol} / \mathrm{g} \text { d.m.] }\end{array}$} & \multirow{3}{*}{$\begin{array}{l}\text { Oznaczone } \\
\text { fosforany } \\
\text { mio-inozytolu } \\
\text { Determined } \\
\text { myo-inositol } \\
\text { phosphates }\end{array}$} \\
\hline & & $\mathrm{IP}_{2}-\mathrm{IP}_{6}$ & $\mathrm{IP}_{6}$ & $\mathrm{IP}_{2}-\mathrm{IP}_{6}$ & $\mathrm{IP}_{6}$ & \\
\hline & & $\overline{\mathrm{x}} \pm \mathrm{SD}$ & $\overline{\mathrm{X}} \pm \mathrm{SD}$ & $\overline{\mathrm{X}} \pm \mathrm{SD}$ & $\overline{\mathrm{x}} \pm \mathrm{SD}$ & \\
\hline VSZ1 & 60,70 & $0,10^{\mathrm{b}} \pm 0,01$ & $0,02^{\mathrm{a}} \pm 0,01$ & $1,5 \pm 0,1$ & $0,3 \pm 0,2$ & $\mathrm{IP}_{6}, \mathrm{IP}_{3}, \mathrm{IP}_{2}$ \\
\hline VSZ2 & 58,20 & $0,11^{\mathrm{b}} \pm 0,01$ & $0,04^{\mathrm{b}} \pm 0,00$ & $1,7 \pm 0,2$ & $0,6 \pm 0,1$ & $\mathrm{IP}_{6}, \mathrm{IP}_{3}, \mathrm{IP}_{2}$ \\
\hline VSP1 & 59,81 & $0,65^{\mathrm{d}} \pm 0,02$ & $0,29^{\mathrm{c}} \pm 0,02$ & $9,9 \pm 0,3$ & $4,4 \pm 0,2$ & $\begin{array}{c}\mathrm{IP}_{6}, \mathrm{IP}_{5}, \mathrm{IP}_{4}, \\
\mathrm{IP}_{3}, \mathrm{IP}_{2} \\
\end{array}$ \\
\hline VSP2 & 60,92 & $0,52^{\mathrm{c}} \pm 0,01$ & $0,26^{\mathrm{c}} \pm 0,01$ & $7,8 \pm 0,1$ & $4,0 \pm 0,2$ & $\begin{array}{c}\mathrm{IP}_{6}, \mathrm{IP}_{5}, \mathrm{IP}_{4}, \\
\mathrm{IP}_{3}, \mathrm{IP}_{2}\end{array}$ \\
\hline VSO1 & 56,12 & $1,27^{\mathrm{e}} \pm 0,05$ & $0,58^{\mathrm{e}} \pm 0,03$ & $19,3 \pm 0,7$ & $8,8 \pm 0,5$ & $\begin{array}{l}\mathrm{InsP}_{6}, \mathrm{InsP}_{5}, \\
\mathrm{Insp}_{4}, \mathrm{InsP}_{3}, \\
\mathrm{InsP}_{2}\end{array}$ \\
\hline VSO2 & 63,94 & $0,54^{\mathrm{c}} \pm 0,01$ & $0,33^{\mathrm{d}} \pm 0,01$ & $8,2 \pm 0,1$ & $5,1 \pm 0,1$ & $\begin{array}{l}\mathrm{InsP}_{6}, \mathrm{InsP}_{5}, \\
\mathrm{Insp}_{4}, \mathrm{InsP}_{3} \\
\mathrm{InsP}_{2} \\
\end{array}$ \\
\hline
\end{tabular}

Objaśnienia jak pod tab. 4. / Explanatory notes as in Tab. 4.

Znacznie większą zawartość sześciofosforanów mio-inozytolu oznaczono w chlebach z mąki graham z pszenicy zwyczajnej (0,29 i $0,26 \%$ s.m.) przy ok. 1,62 \% s.m. tych związków występujących w mące $\mathrm{z}$ tej pszenicy [18]. Nastąpiło zatem ok. 56krotne zmniejszenie zawartości $\mathrm{IP}_{6} \mathrm{~W}$ chlebie pszennym. Największą jednak zawartość tych związków oznaczono w chlebach orkiszowych $(1,27$ i $0,54 \%$ - tab. 11), przy zawartości sześciofosforanów inozytolu w surowcu, czyli w mące orkiszowej, w ilości odpowiednio: 2,05 i 1,66 \% s.m. [18]. Nastąpiło zatem zmniejszenie zawartości $\mathrm{IP}_{6}$ w chlebach odpowiednio: 1,5-krotne i 3-krotne.

Po analizie danych zawartych $\mathrm{w}$ tab. 11. należy podkreślić, że oprócz sześciofosforanów inozytolu $\mathrm{IP}_{6} \mathrm{~W}$ badanych chlebach oznaczono także niższe izomery tego związku - od $\mathrm{IP}_{2}$ do $\mathrm{IP}_{5}$ (tab. 11). Całkowita ilość fitynianów kształtowała się w bada- 
nych chlebach analogicznie do zawartości $\mathrm{IP}_{6}$. Natomiast zaobserwowano istotne różnice pod względem zawartości poszczególnych niższych fosforanów mio-inozytolu. W chlebach żytnich, w których nastąpiła największa degradacja fitynianów, oznaczono izomery $\mathrm{IP}_{6}, \mathrm{IP}_{3}$ oraz $\mathrm{IP}_{2}$. Nie zidentyfikowano izomerów $\mathrm{IP}_{5}$ oraz $\mathrm{IP}_{4}$, co może świadczyć o większej aktywności endogennej fitazy zawartej w mące żytniej, która w większym stopniu rozłożyła sześciofosforan inozytolu do niższych izomerów tego związku - $\mathrm{IP}_{3}$ oraz $\mathrm{IP}_{2}$. Na podstawie współczesnych badań izomerom tym przypisuje się właściwości prozdrowotne, m.in. rolę wewnątrzkomórkowych przekaźników regulujących układ nerwowy i krwionośny czy też związków zapobiegających nowotworom i krystalizacji hydroksyapatytu, który inicjuje powstawanie kamieni nerkowych [21, 29].

W chlebach razowych pszennych, zarówno orkiszowych, jak i z mąki z pszenicy zwyczajnej, także oznaczono wyższe fosforany inozytolu, tj. $\mathrm{IP}_{5} \mathrm{i} \mathrm{IP}_{4}$ oraz fosforany $\mathrm{IP}_{3}$ i $\mathrm{IP}_{2}$. Obecność wyższych fosforanów, zwłaszcza $\mathrm{IP}_{5}$, może świadczyć o mniejszej aktywności fitazy pszennej. Przy takim samym pH zakwasu (ok. 3,7) enzym ten nie był w stanie zhydrolizować sześciofosforanów mio-inozytlou do niższych izomerów, które nie wiążą pierwiastków, ale spełniają inne funkcje w metabolizmie człowieka. Prawdopodobnie $\mathrm{pH}$ wyprodukowanych zakwasów już po pierwszej dobie fermentacji było zbyt niskie dla endogennej fitazy zawartej zarówno w mące pszennej, jak i w żytniej, optymalne bowiem warunki aktywujące ten enzym w mące pszennej to $\mathrm{pH}=5,5$ i temp. $50 \div 55^{\circ} \mathrm{C}$, a w mące żytniej - pH ok. 5,0 i temp. $55^{\circ} \mathrm{C}$. Wydaje się więc, że wobec zbliżonych warunków fermentacji w żurowniku, to większa ilość i aktywność fitazy $\mathrm{w}$ mące żytniej była przyczyną tak radykalnego rozłożenia fitynianów $\mathrm{IP}_{6}$ w czasie pierwszej doby fermentacji, kiedy $\mathrm{pH}$ wynosiło ok. $6,5 \div 4,0$ [18].

Tabela 12. Zawartość akryloamidu w badanych chlebach

Table 12. Content of acrylamide in bread studied

\begin{tabular}{|c|c||}
\hline \multirow{2}{*}{$\begin{array}{c}\text { Rodzaj chleba } \\
\text { Type of bread }\end{array}$} & $\begin{array}{c}\text { Zawartość akryloamidu }[\mu \mathrm{g} / \mathrm{kg} \text { próbki] } \\
\text { Content of acrylamide }[\mu \mathrm{g} / \mathrm{kg} \text { sample] }\end{array}$ \\
\cline { 2 - 3 } & $\overline{\mathrm{x}} \pm \mathrm{SD}$ \\
\hline VSZ1 & $33,83^{\mathrm{b}} \pm 0,01$ \\
\hline VSZ2 & $40,38^{\mathrm{d}} \pm 0,03$ \\
\hline VSO1 & $\begin{array}{c}\text { mniej niż } 20 \text { (poniżej granicy detekcji) } \\
\text { less than } 20 \text { (below level of detection) }\end{array}$ \\
\hline VSO2 & $\begin{array}{l}\text { mniej niż } 20 \text { (poniżej granicy detekcji) } \\
\text { less than } 20 \text { (below level of detection) }\end{array}$ \\
\hline VSP1 & $35,67^{\mathrm{c}} \pm 0,01$ \\
\hline VSP2 & $29,43^{\mathrm{a}} \pm 0,04$ \\
\hline
\end{tabular}

Objaśnienia jak pod tab. 4. / Explanatory notes as in Tab. 4. 
Badanych chlebów nie można uznać za znaczące źródło akryloamidu, jak to przyjmuje się w odniesieniu do chlebów pszennych wypiekanych na drożdżach [10, 19]. Zakwaszenie ciasta, obecność bakterii kwasu mlekowego, a także duża wilgotność miękiszu, dochodząca nawet do $50 \% \mathrm{w}$ chlebach żytnich (rys. 1), ograniczyły powstawanie tego związku, zwłaszcza w chlebach orkiszowych, w których zawartość akryloamidu wynosiła mniej niż $20 \mu \mathrm{g} / \mathrm{kg}$ próbki i okazała się ilością poniżej granicy detekcji HPLC (tab. 12). Przyczyną tego mogła być mniejsza zawartość cukrów prostych (maltozy i glukozy) w tych chlebach (tab. 6).

W badanych chlebach oznaczono zawartość mikotoksyn, jednak zawartość DON i zearalenonu okazała się poniżej poziomu detekcji Aokinmycontrol - systemu do oznaczania mikotoksyn, z wyjątkiem chleba z pszenicy zwyczajnej VSP2, w którym oznaczono śladowe ilości DON (78 $\mu \mathrm{g} / \mathrm{kg}$ próbki) - znacznie mniejsze niż wynosi poziom dopuszczalny przez Rozporządzenie Komisji (WE) [27], czyli $500 \mu \mathrm{g} / \mathrm{kg}$ próbki. Chleb ten jako jedyny nie mógł być oceniony pod względem tekstury miękiszu w końcowym okresie przechowywania, gdyż po 5 dobach uległ spleśnieniu. W tym samym chlebie VSP2 oznaczono największą liczbę drożdży i pleśni $\left(1,6 \times 10^{2}\right.$ jtk/g próbki) spośród wszystkich badanych chlebów (tab. 13).

Tabela 13. Liczba tlenowych bakterii amylolitycznych (OLBA), tlenowych przetrwalnikujących bakterii amylolitycznych (OLBAP) oraz liczba pleśni i drożdży (OLG) po 1., 5. i 7. dobie przechowywania

Table 13. Counts of amylolytic aerobic bacteria (OLBA), amylolytic aerobic spore-forming bacteria (OLBAP), and counts of mould and yeasts (OLG) after the $1^{\text {st }}, 5^{\text {th }}$, and $7^{\text {th }}$ day of storage

\begin{tabular}{|c|c|c|c|c|c|c|c|c|c|}
\hline \multirow{3}{*}{$\begin{array}{c}\text { Rodzaj } \\
\text { chleba } \\
\text { Type of } \\
\text { bread }\end{array}$} & \multicolumn{3}{|c|}{ OLBA } & \multicolumn{3}{|c|}{ OLBAP } & \multicolumn{3}{|c|}{ OLG } \\
\hline & $\begin{array}{c}\text { Po } 1 . \\
\text { dobie } \\
\text { After } 1^{\text {st }} \\
\text { day of } \\
\text { storage }\end{array}$ & $\begin{array}{c}\text { Po } 5 . \\
\text { dobie } \\
\text { After } 5^{\text {th }} \\
\text { day of } \\
\text { storage }\end{array}$ & $\begin{array}{c}\text { Po } 7 . \\
\text { dobie } \\
\text { After } 7^{\text {th }} \\
\text { day of } \\
\text { storage }\end{array}$ & $\begin{array}{c}\text { Po } 1 . \\
\text { dobie } \\
\text { After } 1^{\text {st }} \\
\text { day of } \\
\text { storage }\end{array}$ & $\begin{array}{c}\text { Po } 5 . \\
\text { dobie } \\
\text { After } 5^{\text {th }} \\
\text { day of } \\
\text { storage }\end{array}$ & $\begin{array}{c}\text { Po } 7 . \\
\text { dobie } \\
\text { After } 7^{\text {th }} \\
\text { day of } \\
\text { storage }\end{array}$ & $\begin{array}{c}\text { Po } 1 . \\
\text { dobie } \\
\text { After } 1^{\text {st }} \\
\text { day of } \\
\text { storage }\end{array}$ & $\begin{array}{c}\text { Po } 5 . \\
\text { dobie } \\
\text { After } 5^{\text {th }} \\
\text { day of } \\
\text { storage }\end{array}$ & $\begin{array}{c}\text { Po } 7 . \\
\text { dobie } \\
\text { After } 7^{\text {th }} \\
\text { day of } \\
\text { storage }\end{array}$ \\
\hline & \multicolumn{9}{|c|}{ [jtk/g pieczywa / jtk/g of bread] } \\
\hline VSZ1 & 0 & 0 & 0 & 0 & 0 & 0 & $2,0 \times 10^{1}$ & $1,0 \times 10^{1}$ & $2,0 \times 10^{1}$ \\
\hline VSZ2 & 0 & 0 & 0 & 0 & 0 & 0 & 0 & 0 & $6,0 \times 10^{1}$ \\
\hline VSO1 & 0 & 0 & 0 & 0 & 0 & 0 & 0 & 0 & 0 \\
\hline $\mathrm{VSO} 2$ & 0 & 0 & 0 & 0 & 0 & 0 & 0 & 0 & $\begin{array}{c}1,4 \times 10^{2} \\
\text { drożdże } \\
\text { yeast }\end{array}$ \\
\hline VSP1 & 10 & 0 & 0 & 0 & 0 & 0 & 0 & 0 & 0 \\
\hline VSP2 & 0 & 0 & 0 & 0 & 0 & 0 & 0 & 0 & $1,6 \times 10^{2}$ \\
\hline
\end{tabular}

Należy podkreślić, że wszystkie badane chleby razowe cechowały się dużą trwałością mikrobiologiczną, bowiem minimalna trwałość termostatowa wszystkich rodzajów pieczywa wynosiła 10 dób, tj. 240 h (tab. 14). W badanym pieczywie nie stwier- 
dzono obecności tlenowych bakterii amylolitycznych (OLBA), tlenowych przetrwalnikujących bakterii amylolitycznych (OLBAP), a tylko w pojedynczych przypadkach odnotowano wzrost grzybów strzępkowych, głównie z rodzaju Penicylium i Aspergillus (tab. 13).

Tabela 14. Trwałość mikrobiologiczną pieczywa metodą termostatową

Table 14. Microbiological stability of bread by thermostatic method

\begin{tabular}{|c|c|}
\hline \hline $\begin{array}{c}\text { Rodzaj chleba } \\
\text { Type of bread }\end{array}$ & $\begin{array}{c}\text { Liczba dni bez widocznych objawów } \\
\text { Number of days without visible symptoms }\end{array}$ \\
\hline VSZ1 & $216 \mathrm{~h}(9 \mathrm{dni} /$ days $)$ \\
\hline VSZ2 & $192 \mathrm{~h}(8 \mathrm{dni} /$ days $)$ \\
\hline VSO1 & $264 \mathrm{~h}(11 \mathrm{dni} /$ days $)$ \\
\hline VSO2 & $360 \mathrm{~h}(15 \mathrm{dni} /$ days $)$ \\
\hline VSP1 & $336 \mathrm{~h}(14 \mathrm{dni} /$ days $)$ \\
\hline VSP2 & $456 \mathrm{~h}(19 \mathrm{dni} /$ days $)$ \\
\hline
\end{tabular}

W ocenie profilu tekstury wykonanej teksturometrem TAXT Plus uwzględniono następujące wskaźniki tekstury miękiszu: twardość, spójność, żujność i odbojność. Oznaczono także wilgotność miękiszu, która wywiera znaczący wpływ na wszystkie ww. parametry.

W dniu wypieku największą wilgotnością wyróżniały się chleby żytnie (49 $50 \%$ - rys. 1. Nieznacznie mniejszą zawartość wody oznaczono w miękiszu chlebów pszennych, zarówno z mąki z pszenicy orkiszowej, jak i z pszenicy zwyczajnej. Średnia zawartość wody w tych chlebach wynosiła ok. 47,5 \%. Wydaje się, że większa zawartość wody wywarła korzystny wpływ na twardość miękiszu, chleby z mąki żytniej odznaczały się bowiem najmniej twardym miękiszem - ponad dwukrotnie bardziej miękkim niż oba rodzaje chlebów pszennych (rys. 2) oraz mniejszą żujnością (rys. 3). Chleby te niestety odznaczały się także najmniejszymi wartościami pozostałych parametrów miękiszu, tj. spójności i odbojności, choć nie wszystkie różnice były statystycznie istotne.

Wydaje się, że wpływ na profil tekstury miękiszu wywarła nie tylko jego wilgotność, mógł on zależeć także od sposobu związania i zatrzymania wody przez składniki miękiszu. W mące żytniej składnikami najsilniej wiążącymi wodę są z pewnością pentozany, zaś w chlebach z mąki pszennej - białka glutenowe i skrobia. Pentozany znacznie silniej wiążą wodę w ukwaszonym cieście niż białka glutenowe, zaś skrobia w temperaturze poniżej $60{ }^{\circ} \mathrm{C}$ wykazuje bardzo ograniczoną zdolność wiązania wody maksymalnie $30 \%$ swojej masy [5]. 


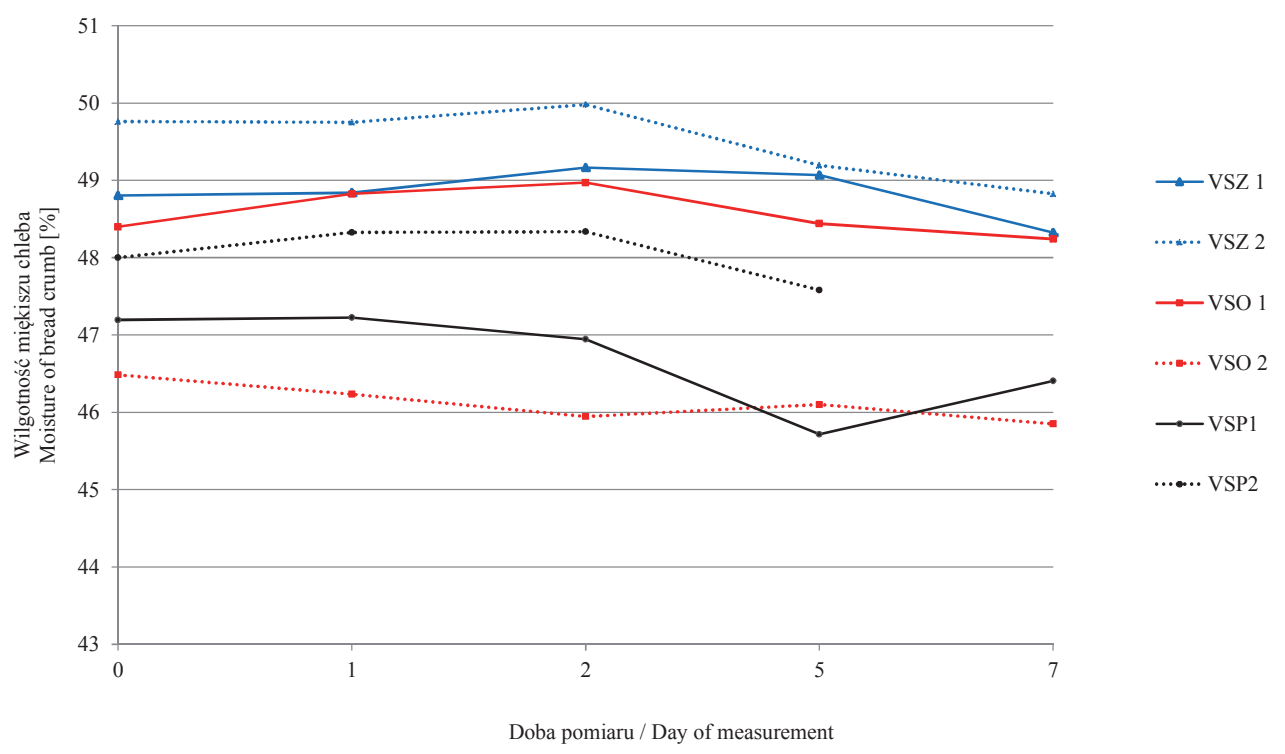

Objaśnienia symboli jak pod tab. 4. / Explanation of symbols as in Tab 4.

Rys. 1. Zmiany wilgotności miękiszu chleba w czasie przechowywania

Fig. 1. Changes in moisture of bread crumb during storage

Podczas wypieku, w miarę wzrostu temperatury w całej objętości bochenka, skrobia sukcesywnie zwiększa zdolność wiązania wody, odciągając ją ze składników, które ją wcześniej zatrzymały. Substancje białkowe łatwiej oddają wodę niż pentozany, stąd skrobia kleikuje w cieście chleba pszennego w znacznie większym stopniu niż w chlebie żytnim. Skleikowana skrobia natychmiast zaczyna retrogradować, tzn. dąży do odzyskania swej krystalicznej struktury, tworząc uporządkowane, twarde regiony w miękiszu chleba. Proces ten postępuje już podczas chłodzenia chleba po wypieku i intensywnie przebiega w czasie pierwszej doby przechowywania, przy czym w kolejnych dniach po wypieku jego intensywność znacznie maleje $[9,12]$.

Badania profilu tekstury miękiszu podczas kolejnych dni przechowywania chlebów potwierdzają powyższą teorię starzenia się miękiszu chleba, gdyż miękisz chlebów żytnich przez cały okres przechowywania odznaczał się wyraźnie mniejszą twardością i żujnością (rys. 2 i 3) niż miękisz obu rodzajów chleba pszennego. Zatem można przypuszczać, że proces retrogradacji skrobi w chlebach pszennych i żytnich przebiegał z różną intensywnością. W chlebach razowych żytnich twardość miękiszu wzrosła od 16 i $18 \mathrm{~N} \mathrm{w}$ dniu wypieku do 22 i $19 \mathrm{~N} \mathrm{w} 7$. dobie przechowywania (rys. 2). W obu rodzajach chlebów pszennych odnotowano natomiast znacznie większy wzrost twardości miękiszu pomiędzy dniem wypieku a 7. dobą przechowywania. W miękiszu chleba orkiszowego wzrost ten wynosił od 40 i $44 \mathrm{~N} \mathrm{w}$ dniu wypieku do 
60 i $65 \mathrm{~N} \mathrm{w} 7$. dobie przechowywania, a w miękiszu chleba z pszenicy zwyczajnej - od 29 i $40 \mathrm{~N}$ w dniu wypieku do 30 i $69 \mathrm{~N} \mathrm{w} 7$. dobie przechowywania (rys. 2). Zmiany twardości miękiszu w obu rodzajach chlebów pszennych były zatem bardzo zbliżone.

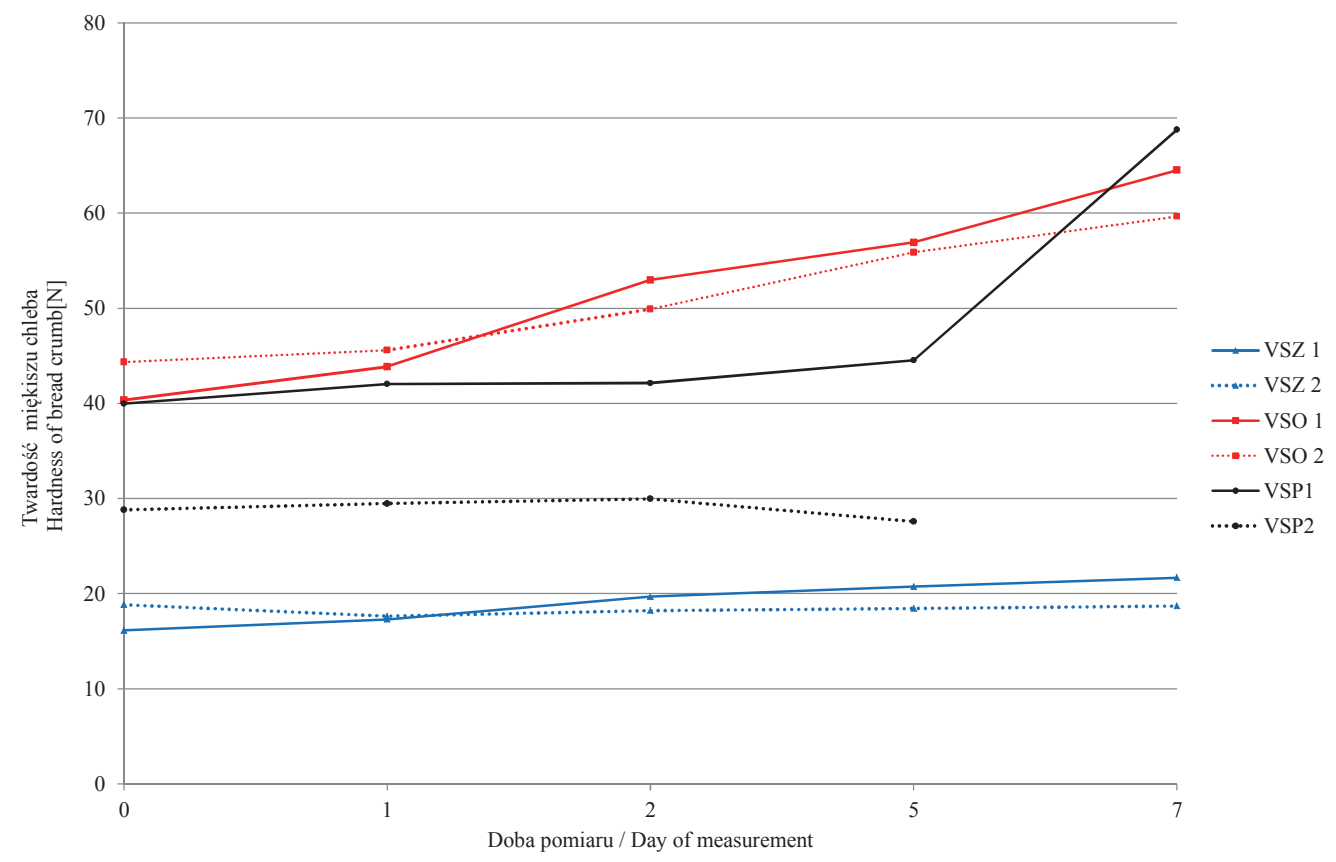

Objaśnienia jak pod tab. 4. / Explanatory notes as in Tab. 4.

Rys. 2. Zmiany twardości miękiszu chleba w czasie przechowywania

Fig. 2. Changes of hardness of bread crumb during storage

Zaobserwowane znaczne różnice twardości miękiszu pomiędzy chlebami z mąki z pszenicy zwyczajnej (rys. 2) można najprawdopodobniej przypisać innej zawartości i jakości glutenu obecnego w tych mąkach, co wykazano we wcześniejszych badaniach Litwinek i wsp. [18]. Wydaje się jednak, że mąka z pszenicy zwyczajnej, która była surowcem do wypieku chleba VSP1, charakteryzowała się dużo słabszym glutenem niż mąka stanowiąca surowiec do wypieku chleba VSP2, bowiem gluten ten nie był w stanie zatrzymać wody podczas wypieku chleba, kiedy pęczniejąca i kleikująca skrobia zaczęła wykazywać aktywność. Skutkowało to w następnej kolejności retrogradacją tej skleikowanej skrobi i dużą twardością miękiszu, sukcesywnie postępującą podczas całego okresu przechowywania (rys. 1). W miękiszu chleba VSP2 zaobserwowano natomiast proces odwrotny. 


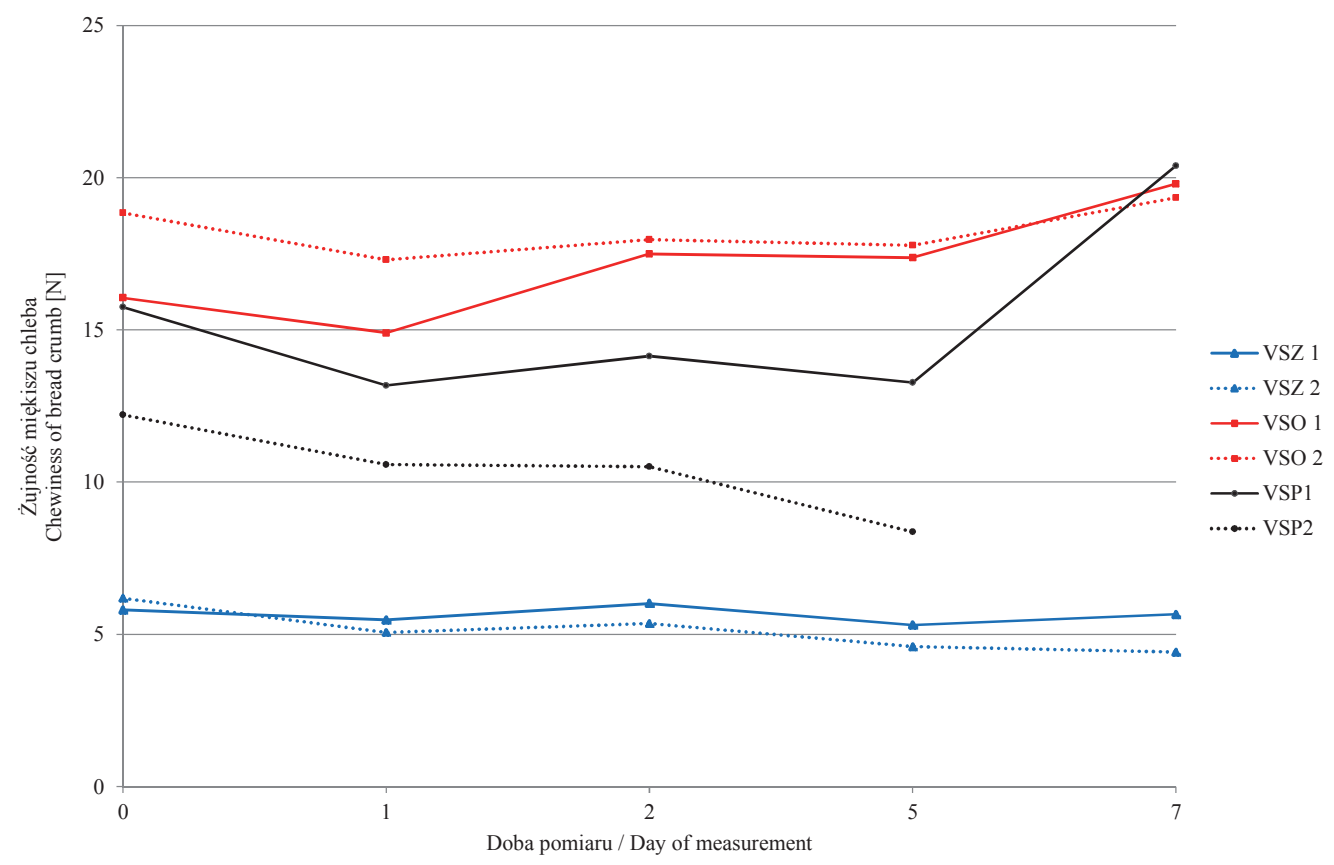

Objaśnienia jak pod tab. 4. / Explanatory notes as in Tab. 4.

Rys. 3. Zmiany żujności miękiszu chleba w czasie przechowywania

Fig. 3. Changes in chewiness of bread crumb during storage

Jak pokazano na rys. 1. i 2., im większa była wilgotność miękiszu, tym mniejsza jego twardość. Zmiany twardości miękiszu były jednak dużo większe niż zmiany jego wilgotności: $46,5 \div 50 \% \mathrm{w}$ dniu wypieku do $46 \div 49 \% \mathrm{w} 7$. dobie przechowywania, tj. o $0,5 \div 1$ p.p. (rys. 1). Efekt ten jest potwierdzeniem, że nie utrata wody przez miękisz jest głównym powodem zwiększania się jego twardości podczas przechowywania, ale zmiany w strukturze skrobi, tj. jej kleikowanie i postępująca retrogradacja $[9,12]$.

Żujność miękiszu badanych chlebów kształtowała się proporcjonalnie do twardości, tzn. jej wartości były najmniejsze w przypadku chlebów żytnich i niewiele zmieniały się podczas przechowywania, w odróżnieniu od miękiszu chlebów pszennych, w których niezależnie od rodzaju żujność miękiszu w niewielkim stopniu wzrastała, z wyjątkiem chleba VSP2 (rys. 3), którego miękisz po 5 dobach uległ spleśnieniu.

Miękisz w chlebach żytnich odznaczał się nieznacznie mniejszą spójnością w dniu wypieku w porównaniu z chlebami pszennymi i tendencja malejąca dotycząca tej cechy utrzymywała się do końca okresu przechowywania. Podobną tendencję wykazano w miękiszu chlebów pszennych (rys. 4).

Miękisz chlebów żytnich odznaczał się w dniu wypieku mniejszą odbojnością niż miękisz chlebów pszennych (rys. 5), a czas przechowywania wpływał ujemnie na tę 
cechę. Podobną tendencję zaobserwowano w miękiszu chlebów pszennych, choć miękisz ten generalnie do końca okresu przechowywania (7 dób) odznaczał się większą odbojnością niż miękisz chlebów żytnich (rys. 5).

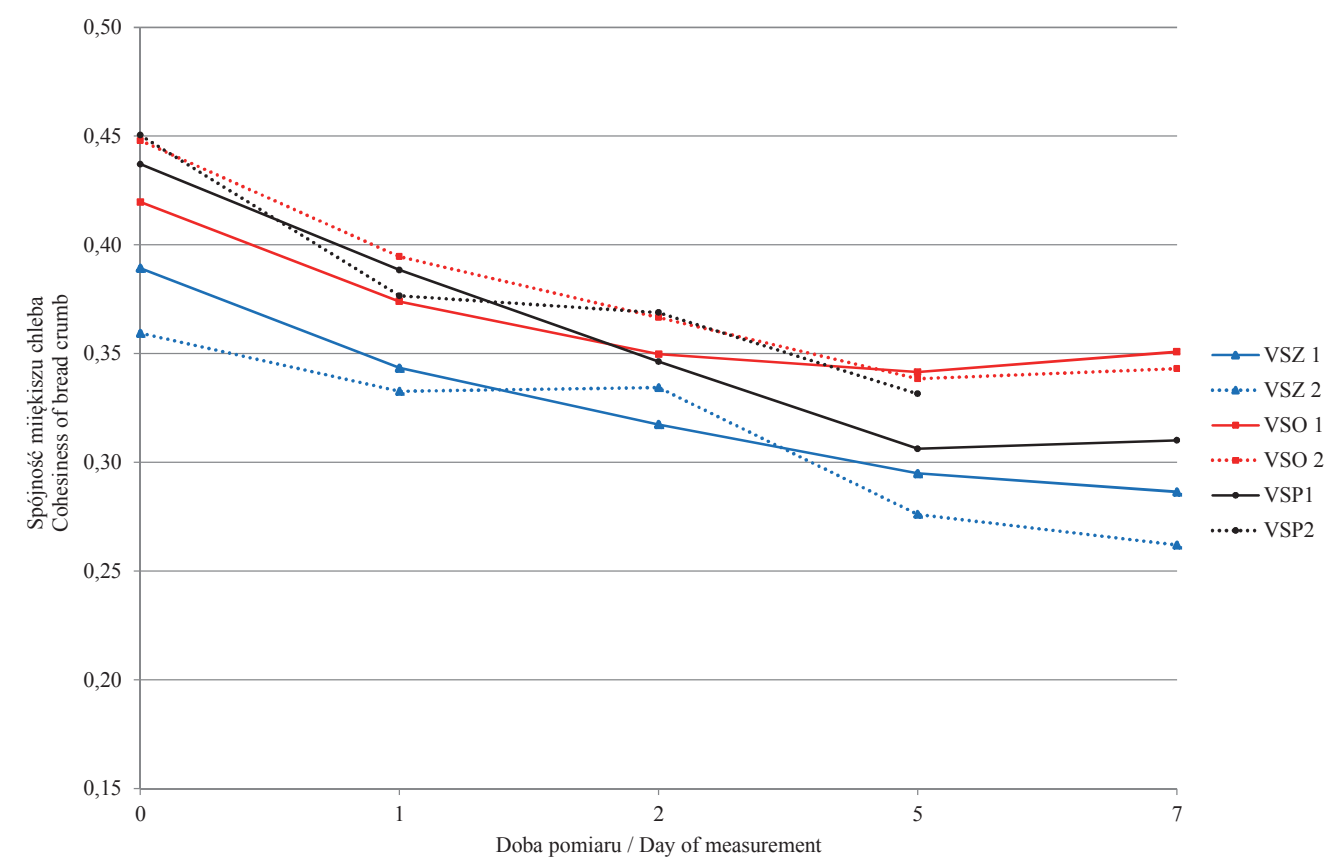

Objaśnienia jak pod tab. 4. / Explanatory notes as in Tab. 4.

Rys. 4. Zmiany spójności miękiszu chleba w czasie przechowywania

Fig. 4. Changes in cohesiveness of bread crumb during storage

Podsumowując, można stwierdzić, że wszystkie zastosowane ukwaszone mąki razowe, tj. pszenna z pszenicy zwyczajnej i orkiszowej oraz żytnia nadawały się do wypieku chlebów. Razowe chleby orkiszowe objętością bochenków były zbliżone do chlebów z mąki żytniej, choć wyraźnie różniły się one smakiem i zapachem zależnym od stosunku kwasu mlekowego do octowego oraz zawartości cukrów prostych w tych chlebach. Najlepiej przez konsumentów został oceniony chleb graham z mąki z pszenicy zwyczajnej, który odznaczał się najmniejszą kwasowością miękiszu. Największą wilgotnością i najmniejszą twardością oraz żujnością miękiszu przez cały okres 7-dobowego przechowywania wyróżniał się chleb żytni, zaś chleby graham i orkiszowy starzały się porównywalnie i znacznie szybciej. 


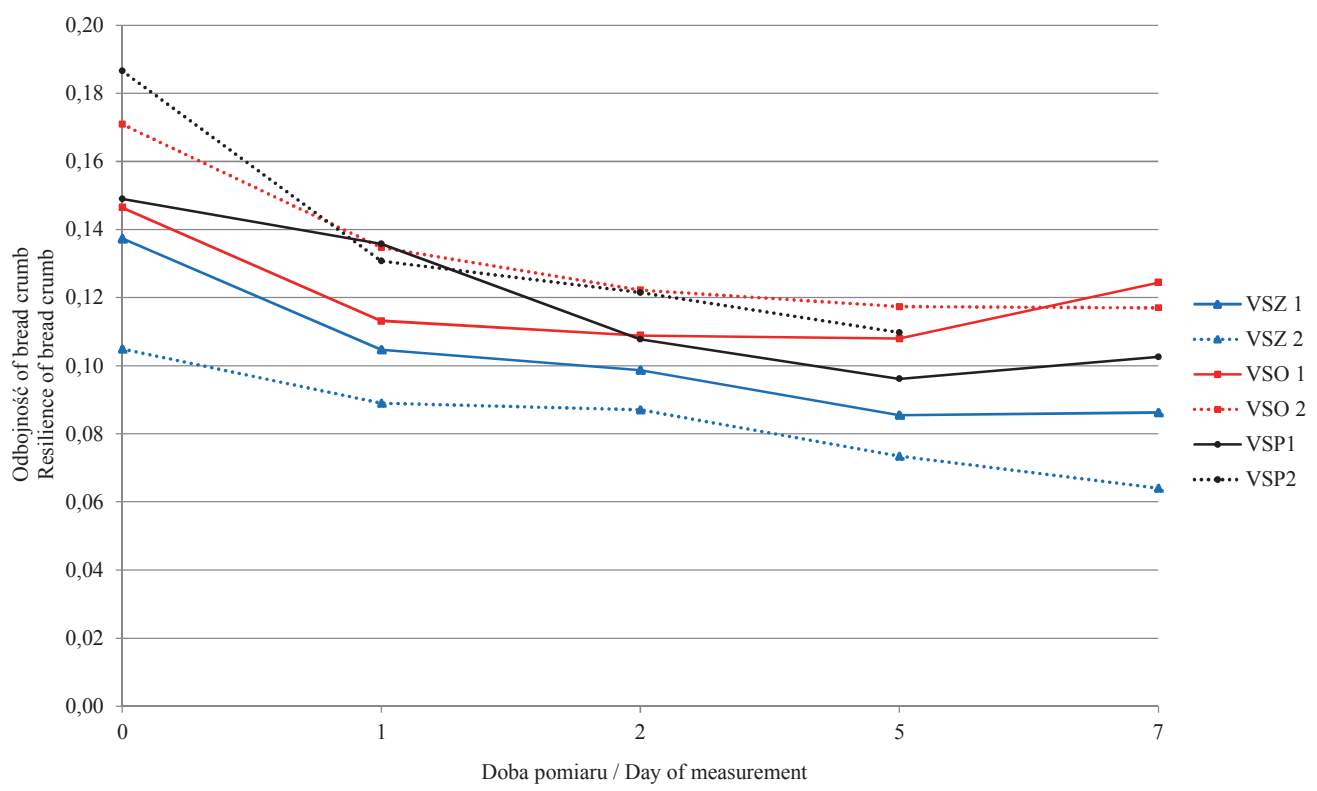

Objaśnienia jak pod tab. 4. / Explanatory notes as in Tab. 4.

Rys. 5. Zmiany odbojności miękiszu chleba w czasie przechowywania

Fig. 5. Changes in resilience of bread crumb during storage

\section{Wnioski}

1. Największą objętością wyróżniały się chleby graham z mąki z pszenicy zwyczajnej i one były najbardziej akceptowane przez konsumentów podczas oceny organoleptycznej, zwłaszcza za smak i zapach. Chleby żytnie i z mąki z pszenicy orkisz były do siebie zbliżone pod względem objętości bochenków, ale większą akceptacją konsumentów wyróżniały się chleby żytnie.

2. W chlebach z mąki pszennej, zarówno graham, jak i orkiszowej, stwierdzono zbliżony stosunek zawartości kwasu mlekowego do octowego, średnio $78: 22$, natomiast w chlebie żytnim było więcej kwasu octowego i stosunek ten wynosił średnio $68: 32$. W chlebie razowym żytnim wykazano też największą zawartość glukozy.

3. W odróżnieniu od chlebów żytnich w chlebach razowych pszennych, zarówno orkiszowych, jak i graham, oprócz zawartości niższych fosforanów mio-inozytolu $\mathrm{IP}_{3}$ i $\mathrm{IP}_{2}$ wykazano także wyższe fosforany tego związku - $\mathrm{IP}_{5}$ i $\mathrm{IP}_{4}$, świadczące o mniejszej aktywności endogennej fitazy pszennej. 
4. Zakwaszenie ciasta, obecność bakterii kwasu mlekowego oraz bardzo duża wilgotność miękiszu ograniczyły powstawanie akryloamidu w badanych chlebach, zwłaszcza wyprodukowanych z mąki pszennej orkiszowej.

5. Badane chleby odznaczały się dużą trwałością mikrobiologiczną, $\mathrm{z}$ wyjątkiem jednego chleba z mąki graham z pszenicy zwyczajnej, na którym stwierdzono oznaki pleśni po 7 dobach przechowywania.

6. W dniu wypieku największą wilgotnością miękiszu wyróżniały się chleby żytnie (ok. $50 \%$ ), natomiast średnia wilgotność miękiszu chlebów pszennych (orkiszowych i graham) wynosiła ok. 47,5\%. W 7. dobie przechowywania wilgotność miękiszu wszystkich chlebów zmniejszyła się w bardzo małym stopniu, o $0,5 \div$ 1 p.p.

7. Mimo niewielkich zmian wilgotności miękiszu zaobserwowano postępujący wzrost jego twardości i żujności podczas przechowywania - najmniejszy w chlebach żytnich.

8. Miękisz chlebów żytnich odznaczał się w dniu wypieku najmniejszą spójnością i odbojnością, a czas przechowywania wpływał ujemnie na te cechy.

Publikacja została sfinansowana ze środków Narodowego Centrum Badań i Rozwoju (PBS2/B8/12/2014 - FunCHLEB)

\section{Literatura}

[1] AOAC: Official Methods of Analysis. $18^{\text {th }}$ ed. Association of Official Analytical Chemists International, Gaithersburg 2006.

[2] Arendt E.K., Ryan L.A.M., Bello F.D.: Impact of sourdough on the texture of bread. Food Microbiol., 2007, 24, 165-174.

[3] Bartnikowska E.: Przetwory z ziarna owsa jako źródła ważnych substancji prozdrowotnych w żywieniu człowieka. Biul. Inst. Hod. Aklim. Rośl., 2003, 229, 235-245.

[4] Bojnanska T., Franakova H.: The use of spelt wheat (Triticum spelta L.) for baking applications. Rostlinna Vyroba, 2002, 48 (4), 141-147.

[5] Bushuk W.: Rye. Production, Chemistry and Technology. AACC, Saint Paul, Minnesota, USA, 2001, pp. 87, 172, 185.

[6] Chen Q.-Ch., Li B.W.: Separation of phytic acid and other related inositol phosphates by highperformance ion chromatography and its applications. J. Chromatogr. A, 2003, 1018, 41-52.

[7] De Vuyst L., Neysns P.: The sourdough microflora: Biodiversity and metabolic interactions. Trends Food Sci. Technol., 2005, 16 (1-3), 43-56.

[8] Abdel-Aal E.-S. M., Rabalski I.: Effect of baking on nutritional properties of starch in organic spelt whole grain products. Food Chem., 2008, 111, 150-156.

[9] Fik M.: Czerstwienie pieczywa i sposoby przedłużania jego świeżości. Żywność. Nauka. Technologia. Jakość, 2004, 2 (39), 5-22.

[10] Friedman M.A.: Chemistry, biochemistry and safety of acrylamide: A review. J. Agric. Food Chem., 2003, 51, 4504-4526. 
[11] Gambuś H., Litwinek D.: Medycyna praktyczna dla pacjentów. Pieczywo - dlaczego warto jeść? [on line]. Dostęp w Internecie [02.10.2012]: http://dieta.pl/zasady

[12] Gambuś H.: Funkcja skrobi w produktach piekarskich. Żywność. Nauka. Technologia. Jakość, 2000, 3 (24), 20-32.

[13] Jakubczyk T., Haber T.: Analiza zbóż i przetworów zbożowych. Wyd. SGGW-AR, Warszawa 1981.

[14] Kasarda D.D., D’Ovidio R.: Deduced amino acid sequence of an $\alpha$-gliadyn gene from spelt wheat (spelta) includes sequences active in celiac disease. Cereal. Chem., 1999, 76, 548-551.

[15] Kawka A.: Przetwory zbożowe - aspekty wzbogacania wartości odżywczej. Przegl. Zboż. Młyn., 2009, 53 (10), 2-7.

[16] Kohajdova Z., Karovicova J.: Nutritional value and banking applications of spelt wheat. Acta Sci. Pol., Technol. Aliment., 2008, 7 (3), 5-14.

[17] Lefebvre D., Gabriel V., Vayssier Y., Fontagné-Faucher C.: Simultaneous HPLC determination of sugars, organic acids and ethanol in sourdough process. LWT - Food Sci. Technol., 2002, 35, 407414.

[18] Litwinek D., Buksa K., Gambuś H., Boreczek J., Kowalczyk M.: Ocena jakości handlowych mąk całoziarnowych - pszennej orkiszowej, pszennej zwyczajnej i żytniej oraz uzyskanych z nich zakwasów spontanicznych. Żywność. Nauka. Technologia. Jakość, 2017, 4 (113), 76-89.

[19] Orzeł D., Biernat J.: Furan i akrylamid w żywności. Bromatol. Chem. Toksykol., 2011, 44 (3), $225-$ 232.

[20] Paleologos E.K., Konotominas M.G.: Determination of acrylamide and methacrylamide by normal phase high performance liquid chromatography and UV detection. J. Chromatogr. A, 2005, 1077 (2), 128-35.

[21] Park H.-R., Ahn H.-J., Kim S.-H., Lee C.-H., Byun M.-W., Lee G.-W.: Determination of the phytic acid levels in infant foods using defferent analytical methods. Food Control, 2006, 17, 727-732.

[22] PN-A-74108:1996. Pieczywo. Metody badań.

[23] PN-A-74134-4:1998. Wyroby i półprodukty ciastkarskie. Badania mikrobiologiczne. Oznaczanie liczby tlenowych bakterii przetrwalnikujących amylolitycznych.

[24] PN-A-74134-6:1998. Wyroby i półprodukty ciastkarskie. Badania mikrobiologiczne. Oznaczanie liczby drożdży i pleśni.

[25] PN-A-74102:1999. Wyroby i półprodukty piekarskie. Pobieranie próbek i metody badań mikrobiologicznych. Załącznik D: Oznaczanie trwałości mikrobiologicznej pieczywa metodą termostatową.

[26] Ranhotra G.S., Geroth J.A., Glaser B.K., Lorenz K.J.: Baking and nutritional qualities of a spelt wheat sample. LWT - Food Sci. Technol., 1995, 28 (1), 118-122.

[27] Rozporządzenie Komisji (WE) nr 1881/2006 z dnia 19 grudnia 2006 r. ustalające najwyższe dopuszczalne poziomy niektórych zanieczyszczeń w środkach spożywczych. Dz. Urz. UE L 364, s. 5-24, z 20.12.2006 z późn. zm.

[28] Shewry P.R., Hey H.: Do "ancient" wheat species differ from modern bread wheat in their contents of bioactive components? J. Cereal Sci., 2015, 65, 236-243.

[29] Szkuderski T.: Phytic acid - its influence on organism. J. Anim. Feed Sci., 1997, 6, 427-438.

[30] Zieliński H., Ceglińska A., Michalska A.: Bioactive compounds in spelt bread. Eur. Food Res. Technol., 2008, 226, \#537, DOI :10.1007/s00217-007-0568-1. 


\title{
QUALITY AND AGING OF BREAD FROM WHOLEMEAL COMMON WHEAT AND SPELT FLOURS, AND FROM WHOLEMEAL RYE FLOUR
}

\author{
S u m m a r y
}

The objective of the research study was to assess the quality of bread baked from wholemeal common wheat and spelt wheat wholemeal flours, and from a rye wholemeal flour using a spontaneous sourdough based on the respective wholemeal flour derived from a given cereal, and to determine the aging process of this bread during storage. In a conventional bakery, spontaneous sourdough starters were made from the above named three types of flour and added to the dough in an appropriate proportion. The $600 \mathrm{~g}$ pieces of the dough were baked and, after cooling, their weight was determined, their volume was measured, a baking loss was calculated, and an organoleptic assessment was performed. In all the bread loaves, there were determined the contents of: water, total protein, dietary fibre (soluble and insoluble fractions), ash (of the selected macro- and microelements), raw fat, some selected micotoxins, myoinositol phospates, substances that give bread its taste and aroma, and acrylamid. Also, the texture profile of bread crumb was measured on the day of baking and during a 7 day period of storage. Moreover, in $1 \mathrm{~g}$ of bread, the count of aerobic amylolytic bacteria (OLBA) was determined as were the counts of sporeforming aerobic amylolytic bacteria (OLBAP), yeasts and moulds (OLG); the thermostatic stability of bread was determined after the $1^{\text {st }}, 2^{\text {nd }}, 5^{\text {th, }}$ and $7^{\text {th }}$ day of storage.

Bread baked from the common wheat Graham flour was characterized by the highest volume and the samples of this bread received, especially for its smell and taste, the highest acceptance of the consumers, who assessed them organoleptically. The rye and spelt bread loaves were characterized by a comparable loaf volume; however, the rye bread was accepted higher by the consumers than the spelt bread. In the bread made from both the common wheat and spelt wheat flour, a similar ratio was determined of lactic to acetic acid (68/32, on average). The highest level of glucose was measured in the rye bread. In contrast to the rye bread, in the bread produced from common and spelt wholemeal flours, there were determined lower contents of myo-inositol phosphates ( $\mathrm{IP}_{3}$ and $\mathrm{IP}_{2}$ ) and higher contents of phosphates of that compound $\left(\mathrm{IP}_{5}\right.$ and $\left.\mathrm{IP}_{4}\right)$. In the bread from spelt wholemeal flour, even trace contents of acrylamide were not found, and in the other bread loaves, trace amounts of this compound were determined. The bread analysed had a high microbiological stability. On the day of baking, the highest moisture content was reported in the rye bread loaves (approx. $50 \%$ ) while the average content of moisture was $47.5 \%$ in the crumb of wheat bread (from common Graham and spelt wheat flour). After 7 days of storage, the moisture content in all the bread loaves decreased to a very low degree: 0.5 to 1 p.p., although their crumbs progressively hardened during storage; the rye bread crumb hardened the slowest.

Key words: wholemeal bread made with spontaneous sourdough from: rye flour, common wheat flour, spelt wheat flour, spontaneous sourdough, bread quality, bread aging 